\title{
Autonomy Orientations of English Language Teachers in Turkey
}

\author{
Aslihan Bagci ${ }^{1}$,Belgin Aydin ${ }^{2}$ \\ ${ }^{1}$ Bilecik Şeyh Edebali University \\ ${ }^{2}$ TED University \\ Correspondence concerning this article should be addressed to Bilecik Şeyh, Edebali University, School of \\ Foreign Languages, 11100 Bilecik, Turkey. E-mail: aslihan.bagci@bilecik.edu.tr

\begin{abstract}
The present study aimed to explore autonomy orientations of English language teachers' work at an intensive language school in Turkey. The autonomy orientations of the teachers were analysed through self-determination theory. The study also investigated if these orientations vary according to the teachers' gender, years of experience, and department of graduation. The investigation was carried out through an autonomy orientations questionnaire. Data were collected from 111 language teachers, 11 of whose opinions were utilized for further analysis. The results showed that teachers had moderate autonomy supportive orientation, which was reported to be risky. Moreover, gender was the only variable that had a significant effect on the autonomy orientations. The teachers mainly blamed the education system for restricting their adoption of the autonomous orientations. The results imply the necessity of explicit training on how teachers can be encouraged to have more autonomy supporting orientations.

Keywords: self-determination theory, intrinsic motivation, autonomy orientations of teachers, autonomy-supportive teaching, foreign language teaching
\end{abstract}

\section{Introduction}

Motivation is the moving power behind every decision that human beings take, and it is widely recognized for its importance in the education research field (Gardner, 1985). It has been put forward that motivation is a very critical factor in determining the effort and energy that learners put into learning activities (Csikszentmihalyi \& Nakamura, 1979; Maehr, 1984; Pintrich et al., 1993).Deci and Ryan's (1985) self-determination theory (SDT) focuses on human motivation and its sources as well as the environment's effects on human motivation.Selfdetermined people are known to take responsibility and make choices about their lives, set their own goals, and do whatever is necessary to reach those goals without being forced by anyone else. They are also more likely to take part in difficult tasks when extrinsic rewards are not accessible, encounter lower levels of performancerelated anxiety, and show more noteworthy levels of learning compared to those with a more extrinsic motivation (Deci \& Ryan, 1985).

In an education context, there is a known positive correlation between learners' intrinsic motivation and the support they get to act autonomously as well as achieve positive learning outcomes (Black \& Deci, 2000; Vandergift, 2005). Considering that students get most of the support from their teachers, teacher behaviors towards students deserve cautious attention. As claimed by Deci, Betley, Kahle, Abrams, and Porac (1981), teachers' instructing habits can range from highly autonomy supportive to highly controlling. Autonomysupportive teachers tend to provide their students with enough time and resources and give them opportunities to express their ideas about their learning process. However, controlling teaching styles hinder students' chances to express themselves (Assor, Kaplan, Kanat-Maymon, \& Roth, 2005).It is known that while studying in a high-pressure environment, students are not able to provide their own solutions and choose what to do or how to do (Reeve, 2002; Reeve, Bolt, \& Cai, 1999; Reeve \& Jang, 2006).

As in all areas of education, having self-determined learners is very important for increasing the effectiveness of foreign language learning. Turkey, as one of the foreign language contexts gives high priority to teaching English to its students in order to enable them to interconnect with the rest of the world. Turkish students start learning English starting at the second grade in the state schools. At the university level, a foundation year is provided to students at schools of foreign languages to help them cope with the requirements of their academic 
fields. Yet, students' motivation levels are reported to drop immediately as soon as they enrol in these intensive language schools because they consider this one-year long education to be an obstacle to the start of their training in their academic fields (Aydın, 2017; Aygün, 2017).

Research focusing on the relationship between teachers' autonomy orientations and their relation to students' motivation is scarce. What is more, it is seen that most studies focus only on the Western societies and this results in a lack of data about Eastern societies, especially in terms of their autonomy orientations. Specifically, in a foreign language teaching and learning environment in Turkey, the teacher is often the main source of input so their behaviours towards their learners gain great importance. In addition, in collectivist societies, teachers are expected to act more controlling in parallel with their cultural norms, as stated by Reeve, et al. (2014). Turkey was found to be the third most collectivist country in the index of 39 countries Oishi, Diener, Suh, and Lucas (1999) created. In studies that are conducted not only with small children but also with older high school or university students, the ones taught by autonomy-supportive teachers were found to have higher academic achievement, higher perceived competence, higher self-esteem, and greater conceptual understanding (Reeve, 2002).Since learners might become more or less autonomous depending on their teachers' supporting or controlling orientations, studying Turkish language teachers might help us reveal the picture for the other collectivist societies as well. Thus, the teachers' autonomy orientations are worthy of investigation because learners might become more autonomous depending on their teachers' orientations. It is believed that by raising Turkish foreign language instructors' awareness of autonomy orientations and the possible effects of those orientations, this study will help create a better learning environment.

SDT focuses on human motivation and its sources as well as the environment's effects on human motivation. SDT claims that every human being is innately prone to continuously develop oneself towards a better self.As argued by Deci and Ryan (1985), self-determination is a universal need for all human beings. When people do not feel free, they find themselves desperate, even falling into amotivation.

In education contexts, motivation has been said to have a boosting effect on the effort learners put into their learning activities, regulating whether they are involved in the task eagerly or apathetically and reluctantly (Csikszentmihalyi \& Nakamura, 1979; Maehr, 1984; Pintrich et al., 1993). The teachers' role is argued to be one of the most critical factors affecting students' learning (Deci \& Ryan, 2002; Richard \& Lockhart, 1994; Wigfield, Tonks, \& Klauda, 2009). If learners have a good relationship with their teachers and if they are motivated, they will be more prone to apply tasks that can possibly help them learn better, namely, paying full attention to what is being instructed, practicing the learning material after the lessons, taking notes, asking for help if necessary, etc. (Yeşilyurt, 2008; Zimmerman, 2000). As referred by Deci \& Ryan (2000), intrinsic motivation is "a natural wellspring of learning and achievement that can be systematically catalysed or undermined by teacher practices (p.55).”

Studies in literature, almost without exception, show that teachers' autonomy-supportive behaviours have positive effects on students as they can enjoy a high level of motivation, sense of involvement, productive learning, and psychological well-being, all resulting in higher academic performance in all their school years (Assor, et al., 2005; Chirkov \& Ryan, 2001; Deci et al., 1981; Roth et al., 2007). In Jang, Reeve, and Deci's study (2010), the student engagement rates were positively predicted by the teachers' autonomy support rates, for which they had observers who rated both the teachers' and students' behaviours at the high school level. Similarly, in a study conducted with 7th graders' by Hofferber, Eckes, and Wilde (2014), focusing on rote learning and conceptual learning, the results revealed that the learners who were educated in an autonomy-supportive setting established a higher level of conceptual knowledge compared to the ones educated in a controlling setting. Yet, learners' rote learning did not change in either case. Griffin (2016) in his study with university students found that not only intrinsic motivation but also autonomy support was positively related to the ratings that the students gave about the instructions they received. In fact, intrinsic motivation had a balancing role, meaning that the higher the intrinsic motivation was the less predictive autonomy support was or vice versa.

In another study conducted with preparatory year students' by Hazaea and Alzubi (2018), it was shown that learners' autonomy increased to a greater degree as the teachers allowed the students to make their own choices of external reading materials. In addition, gaining more autonomy helped the students focus on the lesson objectives more deeply. Baranovskaya and Shaforostova (2018) underlined in their study that even though the significance of autonomy is widely recognized, it is not easy for the instructors to figure out effective strategies 
that can cause a real change in the students' autonomy levels and it is teachers who are responsible for creating a learning environment where students can grow their own autonomy skills. Furthermore, Şakrak-Ekin and Balçıanlı (2019) found a link between their students' language learning achievement and their autonomy levels, showing that learners who take responsibility of their own learning can be more successful in their language learning. It was concluded that the importance of learner autonomy should be stressed and different strategies that can help to promote it inside as well as outside the class must be examined.

When the literature related to foreign language teaching and autonomy orientation of teachers was examined, similar results were obtained. Dörnyei (2005) claimed that teachers whose orientations tend to be autonomy supporting and non-controlling increase foreign language learners' intrinsic motivation and their selfdetermination. Supporting this claim, Wu's study (2003) with young learners of English suggested a positive relationship between higher L2 intrinsic motivation and perceived autonomy of students. Similarly, in Pae and Shin's (2011) study with Korean university students, intrinsic motivation was found to have a relation to EFL achievement only in a classroom where students were given the chance to express themselves freely. Reeve and Jang (2006) showed that pre-service teachers in autonomy-supportive learning environment could reach higher levels of academic achievement compared to those in controlling environments.

Studies have proved that controlling factors are effective for reducing intrinsic motivation and even creating amotivational consequences (Deci, et al., 198; Deci \& Ryan, 1985). Having rewards and punishments, setting a deadline, goals that have been created without asking the opinions of individuals, and undesired competition can be listed as examples of controlling factors. Pelletier et al. (2002) pointed out a close relationship between teachers' autonomous motivation and autonomous teaching environments. In their study, they found that as the teachers received pressure from their management and parents, they became less self-determined about their teaching, which resulted in being more controlling with their students.

There are some studies focusing on teachers' autonomy orientations or students' motivation related to various factors including teachers' gender and experience. The results of these studies, however, showed conflicting results. For example, Reeve et al. (2004) did not find significant differences in students' engagement based on the teachers' gender. Similarly, although Opdenakker and Van Damme (2007) found that teacher gender was not associated with differences in autonomous motivation, their study results revealed that teacher gender can predict successful classroom management, with male teachers maintaining their class management better than female teachers who were perceived to be stricter. On the other hand, analysing the relationship between student learning and female teachers in India, Chudgar and Sankar (2008) revealed a positive relationship between language learning and being taught by a female. Being in a female teacher's classroom was found to be advantageous for language learning in the 2nd through 6th grades. Klassen and Chiu (2010) investigated the effects of teachers' gender and their years of experience on self-efficacy. Years of experience appeared to have a nonlinear relationship with self-efficacy, since it increased as one reached the middle of his/her career and then fell after that point. In terms of gender, female teachers were found to have lower classroom management self-efficacy. In Aelterman et al.'s study (2014), neither teachers' years of teaching experience nor their gender had an association with autonomy support.

There have been a limited number of studies conducted on the autonomy orientations of teachers in the Turkish context. In their study, Güvenç and Güvenç (2014) examined how math and science teachers' autonomy support and classroom management styles varied in terms of their subject and years of experience. It was revealed that teachers' autonomy support was at a medium level and that their autonomy support levels did not vary according to their subject matters or years of experiences. Similarly, in a study conducted by Güvenç (2011) with class teachers, no variance in the teachers' autonomy supports according to their years of experience was found. On the other hand, one difference observed between novice teachers and more experienced teachers was that the novice ones generally had a more controlling approach rather than being autonomy supportive. A positive relationship was also found between academic achievement and intrinsic motivation as well as autonomous learning and academic achievement of Turkish undergraduate students (Karataş, et al., 2015).

In a report the British Council prepared in 2015 after investigating Turkish higher education in detail, it was pointed out that the students had stated that they knew they needed to learn English but they did not want to learn it. For this reason, they considered their one year of foreign language preparatory education to be like a 
holiday. As Aydın (2017) underlined, students who feel helpless due to the curriculum repeated each year and still not making progress start to lose their motivation, which leads to a great problem when they must start university and continue their education related to their profession where they will use the English language. As soon as they step onto the university campus, their negative attitudes about foreign language learning and feelings of failure from their past affect them during their preparatory year (Aydın, 2017). The belief that it is difficult to learn a foreign language and that they cannot learn a foreign language after a certain age affects the motivation of the students even more negatively (Arslan \& Akbarov, 2010).

Studies in the literature prove that autonomy-supportive teaching leads to better learning in many aspects. It is also argued that teachers might be encouraged to adapt a more autonomy-supportive orientation in their classes (Leroy et al., 2007).Hence, it is important to determine the autonomy orientations of the teachers as the first step. Learning English is very important in Turkey especially for those studying in higher education institutions because if they are not successful in their intensive English program, they cannot continue their academic lives. Turkish students are known to be very reluctant towards learning English even though they know that they must follow the literature in both their education and professional lives through English and that they cannot fully watch the media, which is an important part of their lives, without knowing English; this is the core reason why the approach of the English language instructors was specifically investigated in this study. Since this is still an underinvestigated field in the Turkish context, this study aims to reveal how teachers' autonomy orientations vary according to their gender, years of experience, and department of graduation. How Turkish EFL teachers perceived their autonomy orientations was another focus of the study. In Turkey, both graduates of English Language Teaching (ELT) departments and graduates from language-related departments can work as a language teacher at the university level. While ELT graduates have pedagogical courses and are equipped with methods and techniques for language teaching, non-ELT graduates do not always have such a pedagogical background. This was thought to be a variable in teachers' autonomy orientations in this study.

The following research questions were asked for these aims:

1. What are the autonomy orientations of the language teachers at Anadolu University School of Foreign Languages?

2. Do the orientations vary according to the teachers'

a) gender? b) years of experience? c) department of graduation?

3. What are the teachers' perceptions regarding their autonomy orientations?

\section{Materials and Methods}

\section{Participants and Setting}

Being one of the biggest state universities in Turkey, Anadolu University School of Foreign Languages (AUSFL) was chosen as the setting of the study as it offers an intensive language program to university students before they start their education in their academic fields. The participants of the present study were 111 English language teachers at the School of Foreign Languages. Eleven of these participants also voluntarily contributed to the qualitative part of the study, which aimed to gather more detailed data on their autonomy orientations. Since teachers' gender, their years of experience, and majors were variables of the study, they were asked to reveal information regarding these three factors. Figure 1 presents information about the teachers' backgrounds.

As shown in Figure 1, $69.4 \%$ of the participants (77 out of 111) were females while $30.6 \%$ of them (34 out of 111) were males. In terms of the department of graduation, $82 \%$ of the participants were English Language Teaching (ELT) graduates and 18\% of them were non-ELT graduates. When it comes to their years of experience, $6.4 \%$ of them had $0-5$ years of experience, $19.8 \%$ had $6-10$ years, $27 \%$ of them had $11-15$ years, $32.4 \%$ of them had $16-20$ years, and $14.4 \%$ of them had 20 years or more experience in the field. To summarize, the majority of the participants of the study consisted of very experienced females who were graduates of the ELT department.

Eleven participants also volunteered for the open-ended responses that aimed to reveal teachers' perceptions of autonomy orientations in general, and their own orientations in particular with possible explanations for 


\section{ASLIHAN BAGCI,BELGIN AYDIN}

\section{Figure 1}

Teachers' gender, department of graduation, and years of experience

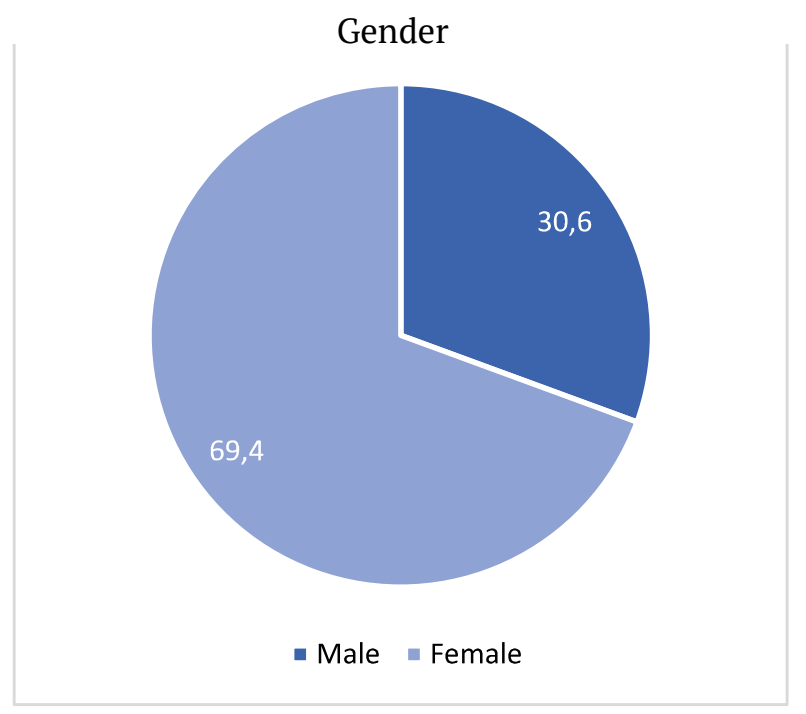

Departamtnt of graduation
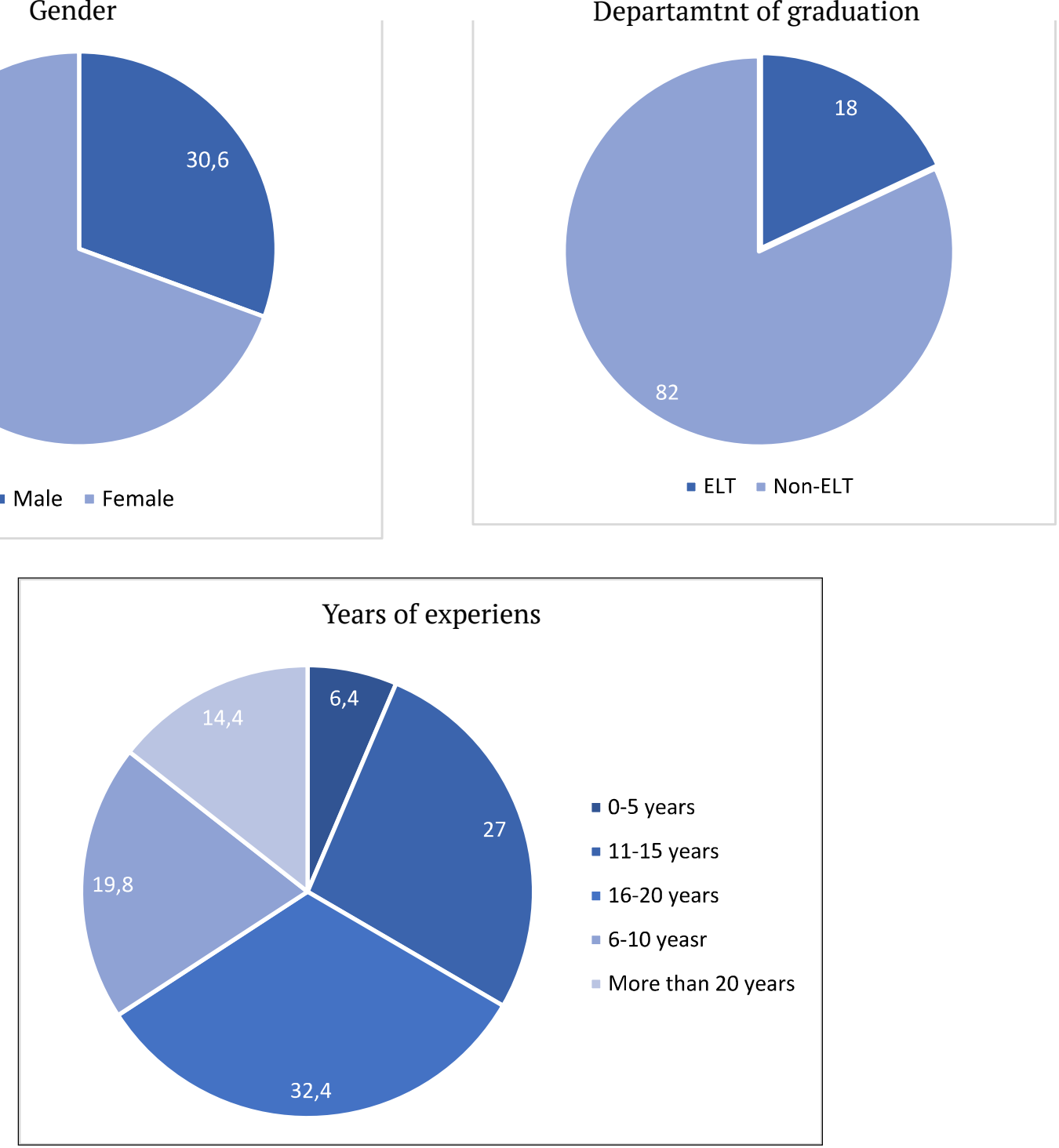

the reasons behind them. Volunteers from the three types of scores on the Autonomy Orientation Questionnaire were chosen; namely, among the teachers who got the highest score (3 autonomy supportive teachers), the lowest score (4 controlling teachers), and average scores (5 moderately autonomy supportive teachers) considering the mean score of all of the participants.

\section{Assessments and Measures}

\section{The Questionnaire}

The main instrument utilized in this study was a questionnaire that aimed to find the extent to which teachers are being controlling or autonomy supportive with their students. Being a type of "Motivators' Orientations Questionnaire", the "Problems in Schools (PIS)" Questionnaire by Deci, Schwartz, Sheinman, and Ryan (1981) was adopted for use in this study. Since the original scale was designed according to the primary and middle school levels, the PIS scale was adapted to the university-level setting with the help of an expert committee. For adaptation, the specific wording used for the school levels in the questionnaire were altered to the ones that would be used in a university setting and the names used for the example vignettes were changed into Turkish ones to help the participants relate to the vignettes more easily. The lexical items and the situations given either 
in the vignettes or in their options were checked and modified to match a university setting. The PIS Questionnaire has eight situations, each including four options of response. The participants were asked to rate the degree of appropriateness of each of the four options (on a 7-point scale) for each situation. Those four options provided for each case represent four sub-scales: Highly Controlling (HC), Moderately Controlling (MC), Moderately Autonomous (MA), and Highly Autonomous (HA). Lastly, in order to be representative of cases teachers might experience in an intensive language teaching context, two more vignettes were added to the questionnaire, making a total of 40 questionnaire items to rate (Appendix A). The new version of the questionnaire was given to five ELT experts to ensure content validity. Overall score that one gets from this questionnaire, ranging from - 180 for Highly Controlling to +180 to Highly Autonomous, gives information about the autonomy orientation of the participant. Zero is considered Neutral. Based on this scale, every positive score gained is considered autonomy supportive and every negative score is considered controlling. The scores up to +90 are considered moderately autonomy supportive and when the score is greater than +90 , it is highly autonomy supportive. Likewise, the scores as low as -90 are considered moderately controlling, and highly controlling if it is lower than - 90 .

\section{Evaluation Guestions}

In order to gain a deeper understanding of teachers' opinions on the autonomy support of their colleagues they are working with in general and their own orientations, 11 of them with low, medium, and high orientations were invited to evaluate the findings of the quantitative part. The participants were asked to share their opinions on the results regarding the autonomy orientation scores as well as their overall opinions on autonomy support and the possible reasons behind these results. The teachers who participated in the qualitative part were asked to write detailed answers to six open-ended questions that were prepared based on the research questions with the guidance of expert opinion (Appendix B).

\section{Data Collection Procedures}

Before administering the questionnaire to the participants, a pilot study was conducted with a similar group of teachers who were working at another intensive langauge program. The possible problems in the scale items such as the appropriateness of the wording or the vignettes to the setting were investigated. After making the necessary modifications considering the opinions of the teachers in the pilot study, the questionnaire was administered to the participants towards the end of the fall semester of the 2017-2018 academic year. On the consent form that was presented online, the participants were informed about the anonymity and confidentiality and were asked to volunteer to participate by the researcher. Demographic information including gender, years of experience and their department of graduation was also added to the questionnaire. After analysing the questionnaire results according to their autonomy orientation scores, 11 participants were asked for their volunteer participation in the second part of the study.

\section{Data Analysis}

The percentages for the gender, years of experience, and department of graduation of the participants were calculated. Then, an overall autonomy score was calculated following the suggested formula by Deci, et al. (1981). Next, to test the normality of the distribution of the 111 participants' autonomy scores, a KolmogorovSmirnov (K-S) test was applied. Since this test is very sensitive to the sample size, the coefficient of skewness was also determined. Proving the normality of distribution meant that parametric statistical methods could be used in order to compare the autonomy orientation scores of the participants in accordance with their demographic information. A t-test was utilized for the relationship between gender and autonomy as well as the relationship between the department of graduation and autonomy scores of the participants. In addition, an ANOVA was used to examine the relationship between the participants' years of experience and their autonomy score. Lastly, the qualitative data were analysed identifying the codes and the themes as suggested in the content analysis scheme of Creswell (2012). This was done by two separate researchers in order to increase inter-rater reliability.

\section{Results}

\section{Results of the Guantitative Data}

The distribution of the autonomy orientations of language teachers obtained from 111 participants is presented in Table 1 below. 
Table 1

Descriptive statistics of the teachers' autonomy orientations

\begin{tabular}{|c|c|}
\hline Statistics & Value \\
\hline Mean & 40.31 \\
\hline Standard Deviation & 20.92 \\
\hline Kurtosis & -.964 \\
\hline Skewness & -.064 \\
\hline Variation & 437.76 \\
\hline
\end{tabular}

Firstly, it should be mentioned that the majority of the teachers had a positive score on the Autonomy Orientation Questionnaire, which meant that autonomy-supportive orientations dominated the controlling ones. The mean score of the 111 participants was 40.31, which falls in the "Moderately Autonomy Supportive" group. The highest score obtained was 82, which was very close to the limit of Highly Autonomy Supportive orientation. The lowest score obtained was -4 , very close to 0 , which was neutral. None of the participants could be considered completely controlling or completely autonomy supportive. An illustration representing the average placement of the participants in the autonomy orientation scale is presented in Figure 2 below.

Figure 2

The place of participants in the autonomy orientation scale

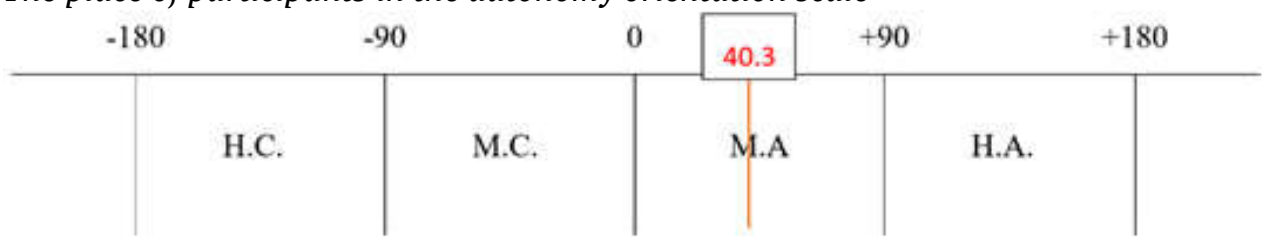

As the second step, a one-sample t-test was applied to test whether the mean score of all the participants was significantly different from the midpoint of the scale, “0”. The results obtained are shown in Table 2.

Table 2

One-sample t-test results

\begin{tabular}{|cccccc}
\hline $\mathbf{N}$ & Mean Score & S.D. & t & d.f. & Significance (p) \\
\hline 111 & 40.31 & 20.92 & 20.3 & 110 & .000 \\
\hline
\end{tabular}

As seen in Table 2, the one-sample t-test results were statistically significant at the .05 level $(\mathrm{p}<.05)$. In other words, the average of the scores obtained from the scale was found to be statistically significant to the reference score " 0 ".

In order to find the teachers' autonomy orientations and their dependence on the teachers' gender, educational background, and experience, fa K-S test was applied and the result that was obtained for the distribution of scores was found to be significant $(\mathrm{p}=.028<.05)$. This value indicates that distribution is not a normal one; thus, the coefficient of skewness was obtained and interpreted. The coefficient of skewness was found to be -.06. Since this value remains within the range of $+/-1$, it can be concluded that the distribution met normality assumptions. As the number of categories in the independent variable category was two, an independent samples t-test was applied to find out the effect of gender on teachers' autonomy orientations.

Table 3

Autonomy orientations and gender

\begin{tabular}{lcccccc}
\hline \multicolumn{1}{c}{ Gender } & N & Mean Score & S.D. & t & d.f. & Significance (p) \\
\hline Male & 34 & 34.18 & 20.17 & -2.08 & 109 & .040 \\
Female & 77 & 43.01 & 20.8 & & & \\
\hline
\end{tabular}


As it can be seen in Table 3 above, the mean of the males' scores was 34.18 while it was 43.01 for the females. The difference between the mean of the scores was found statistically significant at the 0.05 level $(p=.040<.05)$, concluding that the female EFL teachers had higher autonomy support scores compared to the males.

Having the differences between the means in the results of both $\mathrm{t}$-test and variation analysis be significant is not usually sufficient because these analyses cannot provide a variation rate of the independent variable's power of explanation for the dependent variable. Therefore, the effect size was measured. In this study, the effect size was obtained through Cohen's d coefficient for the analyses conducted for t-tests in cases where the difference between means was significant. Cohen's coefficient to measure effect size was found to be 0.44 . This value can be interpreted as the difference between the means of scores having a medium effect size in practice.

To identify if teachers' autonomy orientations varied depending on their teaching experience, they were categorized into five groups as having $0-5$ years, 6-10 years, 11-15 years, 16-20 years, and more than 20 years of experience; then a one-way ANOVA was applied to test whether EFL teachers' autonomy orientations varied across these five categories. Firstly, the homogeneity of variations was reported with the Levene test. According to the obtained results, the Levene test was not found statistically significant at the .05 level $(p=.277>.05)$. Since this condition means that the pre-requisition of variation homogeneity was met, the ANOVA table was interpreted for reporting descriptive statistics. Table 4 is presented below.

Table 4

Autonomy orientations and experience

\begin{tabular}{llll}
\hline \multicolumn{1}{c}{ Experience } & N & Mean \\
Score & S.D. \\
\hline 0-5 years & 7 & 37.57 & 27.50 \\
6-10 years & 22 & 43.86 & 21.16 \\
$11-15$ years & 29 & 46.44 & 16.13 \\
$16-20$ years & 36 & 39.25 & 21.35 \\
$20+$ & 17 & 28.58 & 21.16 \\
\hline
\end{tabular}

The highest mean score of 46.4 belonged to teachers with 11 to 15 years of experience. This was followed by the teachers with 6 to 10 years of experience $(M=43.9), 16$ to 20 years $(M=39.3)$ and 0 to 5 years $(M=37.6)$. The lowest mean score belonged to the teachers who had the most teaching experience, with a mean of 28.6. Although the most experienced teacher group had the lowest autonomy orientation score, these results were not found statistically significant. The related table is presented below.

Table 5

The variation analysis results of the autonomy orientations

\begin{tabular}{lcccc}
\hline & $\begin{array}{c}\text { Sum } \\
\text { of squares }\end{array}$ & d.f. & F & $\begin{array}{c}\text { Significance } \\
(\mathbf{p})\end{array}$ \\
\hline Within Groups & 3799.24 & 4 & 2.27 & .066 \\
Between Groups & 44354.34 & 106 & & \\
Total & 48153.58 & 110 & & \\
\hline
\end{tabular}

As seen in Table 5 , since $\mathrm{P}=.066>.05$, was found insignificant, it is possible to conclude that autonomy orientation scores did not vary according to the participants' years of experience.

In order to find out the effect of educational background on teachers' autonomy orientations, the participants were divided into the ones graduating from English Language Teaching (ELT) departments and the ones graduating from the other departments (non-ELT). An independent samples t-test was applied to find the answer for this sub-question. The obtained results are presented in Table 6. 
Table 6

Autonomy orientations and departments of graduation

\begin{tabular}{lllllll}
\hline Graduation & $\mathrm{N}$ & Mean Score & S.D. & $\mathrm{t}$ & d.f. & Significance (p) \\
\hline ELT & 91 & 39.17 & 20.24 & -1.22 & 109 & .226 \\
Non-ELT & 20 & 45.45 & 20.65 & & & \\
\hline
\end{tabular}

As a result, the mean scores of teachers who graduated from English Language Teaching departments was identified as 39.17 while the mean of scores non EFL graduates was 45.45. Although the non-ELT graduates had a higher autonomy orientation score compared to ELT graduates, this difference was not found to be statistically significant $(\mathrm{p}=.226>.05)$.

\section{Teachers' Interpretations of their Orientations}

The teachers who participated in the qualitative part were asked to interpret the overall results, the possible reasons behind these results, as well as their own individual scores compared with the others in the group.

The teachers interpreted a moderate autonomy-supportive orientation as having "outdated educational beliefs in Turkey" and following an "inflexible syllabus". They thought females were more autonomy supportive because of "the natural inherited differences between males and females". Participants believed that all teachers "adapt to the context of the institution in which they work", that is why, years of experience or the department of graduation didn't make a significant difference.As another explanation, the "personality of the teacher", which does not change with experience or graduation, was suggested by the participants. Some teachers also stated that "being more familiar with the latest technological and educational trends" could the motive for less experienced teachers having a more autonomy-supportive orientation.

When it comes to interpreting the participants' own personal autonomy orientation scores, the possible reasons listed were "personal self-development efforts", "inflexible syllabi", and the "problems with the Turkish educational belief system" for all teachers from all autonomy orientation scores. They also stated that since "supporting autonomy leads to better learning”, EFL teachers should be more autonomy supportive. Finally, when the teachers were asked for their suggestions for other EFL teachers to become more autonomy supportive, most of them felt the need for "institutionally organized workshops and seminars" as well as "a more flexible syllabus".It should be highlighted that similar ideas were shared by the teachers from all levels of autonomy orientation, including very high scoring and very low scoring teachers. For example, one teacher with a moderate controlling score mentioned trying to find ways to foster learner autonomy by working on her personal development by reading recent articles, while another teacher whose score was quite above the average mentioned negative ideas such as the syllabus stopping him from being creative and autonomy supportive.

\section{Discussion}

The results of the study indicated that the EFL teachers working at AUSFL had a moderate autonomy-supportive orientation with a mean score of $+40,3$, which is actually close to being controlling.Thus, it is possible to state that even though language teachers are currently in the autonomy-supportive area, there is a risk of exhibiting a more controlling approach towards their teaching. In fact, there were a few participants who actually had scores lower than zero (-4 and -3$)$. There might be several reasons for this result. The first one is teachers' belief that since the schools of foreign languages have to ensure systematicity and coordination, they have to follow a common syllabus with common materials and assessment for a crowded group of learners and teachers.This might create a feeling of not being able to act autonomously. Yet, this belief also discloses that teachers do not have clear ideas about what autonomy-supportive teaching is and how they can facilitate it for their learners, as also argued by Reeve and Jang (2006). The following quotation from a high-scoring teacher supports this idea of teachers' beliefs regarding standardized applications:

- While trying to fit into a well-detailed schedule and assign a number of tasks, we may be gaining more control over the students... (T1) (Score: +80$)$ 
Teachers also blamed the lack of autonomy support on the Turkish education system for their own autonomy orientation. Moreover, they believed that autonomy was something for the students, rather than the teachers, as seen in the except below:

- In my opinion, "autonomy" is a term to which Turkish students are strangers. They are led or even interfered with by their families or teachers till they come to university so much that they sometimes get lost or do not know what to do when they are not led. (T6) (Score: +39)

It is worth adding Maehr's (1976) claim here that supporting or not supporting the psychological needs of the learners, which will in return lead to intrinsic motivation, can be a cultural matter. Schools exist within a society and they are influenced by public policy as well as the cultural milieu. If the culture is pressuring people to be successful, it may become rather difficult for the teachers and the administrators to be able to maintain an autonomy-supportive orientation in the classroom. Supporting this view in his study, Peacock (2001) found significant differences in the teaching styles among teachers by ethnic origin, which points to culture being the source of those perceptions. In addition, Reeve, et al. (2014) argue that a society's collectivist or individualistic orientations predict its teachers' autonomy orientations. In their study, teachers who lived and worked in collectivist cultures self-reported adopting a more controlling style; stating that they believed it to be the right classroom practice according to their cultural norms. Parallel to this finding, Kozan, Ergin, and Varoğlu (2007) argued that Turkish organizations are known for their centralized decision making, strong leadership, and collectivist orientation, all of which can cause Turkish schools to adopt similar orientations. That might be the rationale behind teachers' beliefs that they cannot act autonomously even if they are working with university-level students who are expected to act independently and be more responsible for their own learning.

The findings revealed significant differences between male and female teachers' autonomy orientations, females having higher autonomy support scores. Although there aren't many studies focusing on the gender factor, Chudgar and Sankar's (2008) and Özkal and Demirkol's (2014) studies found female teachers to be more autonomy supportive compared to their male colleagues. This result can be been explained by females' having been found to be more emphatic and more forgiving compared to males (Broidy, et al., 2003; Hoffman, 1977). Females' communication skills and their ability to create more equally distributed social relations, while males tend to be more dominant, might also be presented as an explanation as to why females can be more autonomy supportive (Merchant, 2012). Furthermore, Strober and Tyack (1980) argued that by being mothers, women need to be patient, nurturing, and understanding, all of which cause them to be more supportive and "better teachers than men" (p.496). In their responses, Turkish teachers in this study also claimed that inborn and later gained characteristic differences between males and females, as well as their power relationships, may be the reason behind this significant result. The extract below explains this difference:

- The possible reason for this is the sexist stereotypes the society imposes. Or, the reasons could simply be rooted in some cliché gender-oriented generalizations. For example-with all the shame of saying this- and totally not a supportive of the cliché- men are bossier. (T1) (Score: +80)

It appeared that while younger teachers appeared to be less controlling, the most experienced teacher group where teachers had more than 20 years of experience, had the most controlling orientation. This may be a result of the changing student profiles and the technological gap that is expanding between the older generation of teachers and the students. Since the new generation is thought to be digital natives and the older generation of teachers are identified as being more digital immigrants (McMahon, 2016), the senior teachers may not feel sufficiently equipped when addressing the new generations, which might in turn lead them towards holding a more controlling approach. Supporting this result, Nakata (2011) argues that having more years of experience, especially in an exam-oriented educational context might be seriously undermining the practices of autonomy. However, considering the fact that the autonomy orientation scores did not have any significance statistically according to the participants' years of experience, the differences observed in the sample cannot be used as a basis for making a deduction towards the population. According to the participants, adapting to the environment in which one works was the main reason for not finding significant differences according to experience variable. The quotation below from a moderately controlling teacher exemplifies this: 
- When you start working in an institution that has specific goals, the effects of experience and graduation start to lose their importance. In order to keep the balance, the needs of the institutional goals, you feel the need to change and be more autonomous. (T2) (Score: -3)

No significant differences were observed between EFL teachers' department of graduation and autonomy orientations. While ELT graduates might be expected to be more autonomy supportive due to having a more comprehensive pedagogic education, the lack of explicit training on learner autonomy, like other affective variables during pre-service teacher education, might be the reason of this insignificance. Contrary to the expectations, the non-ELT graduates were found to have higher autonomy orientations scores. As illustrated in the following quotation, personal professional efforts such as participating in a CELTA training program mattered more than their previous educational background:

- The main reason could be CELTA, during which I got more insight into allocating more time to students for activities they conduct on their own. Another reason is my belief that -taking their ages into account- as they are the learners, they should decide how to learn if not what to learn. This gives them the opportunity to choose the better and also more enjoyable way to learn.(T1) (Score:80)

The teachers' evaluations revealed mostly similar opinions for the reasons behind their autonomy orientations. Thus, it can be argued that the teachers' opinions were not shaped according to their autonomy orientations. For example, language teachers with a wide variety of scores seemed to agree with each other in terms of the gender-related results, namely females being more autonomy supportive compared to males. Moreover, teachers with high, low, and average autonomy orientations mentioned the same reasons about the fact that years of experience and department of graduation did not make a difference on teachers' autonomy orientations. Personality factors and adapting to the work environment were their explanations. There was not a group of high scorers or low scorers claiming any different reasons. To sum up, teachers can have every different scores yet share similar ideas, all depending on their interpretations of the system they are living in; a teacher with a moderate controlling score can mention working on her personal development by reading recent articles and trying to find ways to foster learner autonomy, whereas another teacher with a score quite above the average can blame the syllabus for stopping him from being creative and autonomy supportive. Thus, starting by identifying teachers' beliefs and the rationale behind these beliefs should be the first step in encouraging teachers to act more autonomously and only then can they act as role models for their students in their journeys to become more autonomous learners.

\section{Conclusion}

The results of this study found that the majority of language teachers had autonomy-supportive orientations. There was no teacher who was completely controlling or completely autonomy supportive. Yet, the average scores were not far from being in the controlling zone. Gender was the only factor making a difference in teachers' orientations; female teachers were identified as more supportive. No significant differences were observed in terms of teachers' experience or their department of graduation and autonomy orientations. The teachers' explanations mainly blamed the lack of autonomy support on the Turkish education system for their own autonomy orientation scores. Their opinions also disclosed that they did not have clear ideas about what autonomy-supportive teaching was or how they could facilitate it for their learners. The teachers' responses also revealed that their autonomy orientations and their perceptions did not match. It seems, after all, that how teachers perceive the world around them is very important for the decisions and deductions they make, yet this does not seem to be related to how autonomy supportive they are. This can be the key in terms of creating a more autonomy-supportive environment. The teachers' negative perceptions causing them to think that their power is limited also affects the way they perceive their roles and the options available to them.

The results of this study have some significant implications for language teachers as well as administrators. Inservice and pre-service education programs can also benefit from the findings. Firstly, it should be made explicit to all teachers that supporting learners' autonomy leads to better learning (Reeve \& Jang, 2006). Thus, teachers should be encouraged to raise their own awareness on their individual choices for becoming autonomous. They need to be informed that creating and maintaining an autonomy-supportive climate in their classrooms is under their control and being autonomous is not a responsibility of the learners only. Explicit 
training on what autonomy-supportive teaching is, how it can be encouraged, and what learners' and teachers' responsibilities are were suggested by almost all of the participants of the study. Showing real examples of autonomy-supportive actions by teachers as well as how the language they use and the decisions they make affect their students might be suggested as the most effective methods of training for the teachers. Sometimes just encouraging teachers to see events from different perspectives might be enough. As suggested by the teachers' verbal feedback. this might have a tremendous effect on students' development and teachers' awareness on this effect should be increased.

Being aware of the autonomy orientations of the teachers in their institutions might help administrators make decisions that will lead to a better learning environment in their institutions. For example, if there is more than one teacher instructing a class, a balanced combination of teachers can be assigned to a group of students; that is, rather than two controlling teachers teaching the same class, one autonomy supportive teacher together with one controlling teacher can be a better arrangement for creating a fair teaching environment and giving students opportunities to practice becoming autonomous language learners.

The insights gained from this study may also contribute to the design of and both pre- and in-service training programs by providing opportunities for the teachers to make choices and internalize the rationales behind events that are beyond the students' control. This way, rather than demanding a more flexible syllabus, teachers can realise their own power and start making their teaching more autonomy supportive by giving students opportunities to become autonomous language learners. Finally, if pre-service teachers can have a chance to experience autonomy support themselves, they can be more prone to supporting their students' autonomy when they start teaching in their own classes. This way, higher levels of autonomy support can be transferred to the next generations.

\section{Limitations and Future Directions}

The main limitation of this study is that the findings here cannot be generalized to all language schools, nor to all language teachers, because a more representative sample of Turkish teachers is needed. This study was conducted in one representing university and can simply be regarded as a case study; whether the language teachers in this study are autonomous or not may not be applied to all Turkish language teachers or language teachers in general. A more representative sample of Turkish teachers should be involved in order to be able to make generalizations. Examining the teachers' perceptions of the possible factors affecting their autonomy as well as their suggestions to address the issue might be considered good first steps for encouraging them to act more autonomously. What is more, teachers' perceptions, their levels of autonomy, the possible factors affecting their autonomy, and the corresponding solutions can be examined in future studies. Since autonomy support is a learnable concept, it may be very beneficial to study the autonomy orientations of the teachers working with young learners and setting up training sessions. Lastly, after organizing awareness-raising training on autonomy support, the post-effects of those training sessions can be investigated. All in all, one should not forget, no matter how well a training program is designed, its success depends on the teachers who apply what they learned from it (Aydın, 2017). Therefore, a training program concerning the motivation orientations of the EFL teachers working in schools of foreign languages seems to be necessary.

\section{Conflict of interests}

There are no conflicts to declare in the present study.

\section{References}

Aelterman, N., Vansteenkiste, M., Van den Berghe, L., De Meyer, J., \& Haerens, L. (2014). Fostering a needsupportive teaching style: Intervention effects on physical education teachers' beliefs and teaching behaviors. Journal of Sport and Exercise Psychology, 36(6), 595-609. https://doi.org/10.1123/jsep.2013-0229

Arslan, M., \& Akbarov, A. (2010). Türkiye’de yabanci dil öğretiminde motivasyon-yöntem sorunu ve çözüm önerileri [The matter of motivation-method and solution offers in foreign language teaching in Turkey]. Selçuk Üniversitesi Edebiyat Fakültesi Dergisi, 24, 179-191. 
Assor, A., Kaplan, H., Kanat-Maymon, Y., \& Roth, G. (2005). Directly controlling teacher behaviors as predictors of poor motivation and engagement in girls and boys: The role of anger and anxiety. Learning and Instruction, 15(5), 397-413. https://doi.org/10.1016/j.learninstruc.2005.07.008

Aydın, B. (2017). Türkiye'de hazırlı okullarında yaşanan sorunlara bir çözüm önerisi: Anadolu Üniversitesi örneği [Solutions for the problems of a preparatory school in Turkey's Anadolu University instance]. Pegem Yayınları. Aygün, Ö. (2017). A scale of Turkish preparatory school university students' demotivational factors towards learning Englis [Unpublished master's dissertation]. Anadolu University.

Baranovskaya, T., \& Shaforostova, V. (2018). Learner Autonomy through Role Plays in English Language Teaching. Journal of Language and Education, 4(4), 8-19. https://jle.hse.ru/article/view/7942

Black, A. E., \& Deci, E. L. (2000). The effects of instructors' autonomy support and students'autonomous motivation on learning organic chemistry: A self-determination theory perspective. Science Education, 84, 740-756. https://doi.org/10.1002/1098-237X(200011)84:6<740::AID-SCE4>3.0.CO;2-3

British Council. (2015). The state of English in higher education in Turkey: A baseline study. Yorum Basın Yayın Sanayi Ltd.

Broidy,L.,Cauffman,E.,Espelage,D.L.,Mazerolle,P., \&Piquero,A.(2003).Sexdifferencesinempathyandits relation to juvenile offending. Violence and Victims, 18(5), 503-516. https://doi.org/10.1891/088667003780928143

Chirkov, V. I., \& Ryan, R. M. (2001). Parent and teacher autonomy-support in Russian and US adolescents: Common effects on well-being and academic motivation. Journal of Cross-cultural Psychology, 32(5), 618-635. https://doi.org/10.1177/0022022101032005006

Chudgar, A., \& Sankar, V. (2008). The relationship between teacher gender and student achievement: Evidence from five Indian states. Compare, 38(5), 627-642. https://doi.org/10.1080/03057920802351465

Creswell, J. W. (2012). Educational research: Planning, conducting, and evaluating quantitative and qualitative research (4th ed.). Pearson.

Csikszentmihalyi, M., \& Nakamura, J. (1989). The dynamics of intrinsic motivation: A study of adolescents. In R. Ames, \& C. Ames (Eds.), Research on motivation in education: Goals and cognitions (pp. 45-71). Academic Press.

Deci, E. L., \& Ryan, R. M. (2000). The" what" and" why" of goal pursuits: Human needs and the self-determination of behavior. Psychological Inquiry, 11(4), 227-268. https://doi.org/10.1207/S15327965PLI1104_01

Deci, E. L., Betley, G., Kahle, J., Abrams, L., \& Porac, J.(1981). When trying to win: Competition and intrinsic motivation. Personality and social psychology bulletin, 7(1),79-83. https://psycnet.apa.org/doi/10.1177/014616728171012

Deci, E. L., Schwartz, A. J., Sheinman, L., \& Ryan, R. M. (1981). An instrument to assess adults' orientations toward control versus autonomy with children: Reflections on intrinsic motivation and perceived competence. Journal of Educational Psychology, 73(5), 642-650. https://psycnet.apa.org/doi/10.1037/0022-0663.73.5.642

Deci, E., \& Ryan, R. M. (1985). Intrinsic motivation and Self-Determination in human behavior. Springer Science and Business Media.

Dörnyei, Z. (2005). The psychology of the language learner: Individual differences in second language acquisition. Erlbaum.

Gardner, Robert C. (1985) Social psychology and second language learning. Edward Arnold.

Griffin, B. W. (2016). Perceived autonomy support, intrinsic motivation, and student ratings of instruction. Studies in Educational Evaluation, 51, 116-125. https://doi.org/10.1016/j.stueduc.2016.10.007

Güvenç, E. \& Güvenç, H. (2014). İlköğretim matematik ile fen ve teknoloji öğretmenlerinin sınıf yönetim biçemleri ve özerklik desteği algıları [Classroom management styles and autonomy support perceptions of primary school mathematics and science and technology teachers]. NWSA-Education Sciences, 9(3), 311-322

Güvenç, H. (2011). Sınıf öğretmenlerinin özerklik destekleri ve mesleki özyeterlik algıları [Autonomy supports and professional self-efficacy perceptions of classroom teachers]. Kuram ve Uygulamada Egitim Yönetimi Dergisi, 17(1), 99-116.

Hargreaves, E. (2014) The practice of promoting primary pupils' autonomy: Examples of teacher feedback, Educational Research, 56(3), 295-309. https://doi.org/10.1080/00131881.2014.934554

Hazaea, A. N., \& Alzubi, A. A. (2018). Impact of mobile assisted languagelLearning on learner autonomy in EFL reading context. Journal of Language and Education, 4(2), 48-58. https://doi.org/10.17323/2411-7390-20184-2-48-58

Hofferber, N., Eckes, A., \& Wilde, M. (2014). Effects of autonomy supportive vs. Controlling teachers' behavior on students' achievements. European Journal of Educational Research, 3(4), 177-184. https://doi.org/10.12973/ eu-jer.3.4.177

Hoffman, M. L. (1977). Sex differences in empathy and related behaviors. Psychological Bulletin, 84(4), 712-722 https://doi.org/10.1037/0033-2909.84.4.712 
Hu, P., \& Zhang, J. (2017). A pathway to learner autonomy: a self-determination theory perspective. Asia Pacific Education Review, 18(1), 147-157. https://doi.org/10.1007/s12564-016-9468-z

Jang, H., Reeve, J., \& Deci, E. L. (2010). Engaging students in learning activities: It's not autonomy support or structure, but autonomy support and structure. Journal of Educational Psychology,102(3), 588-600. https://doi. org/10.1037/a0019682

Karatas, H., Alci, B., Yurtseven, N., \& Yuksel, H. G. (2015). Prediction of ELT students' academic (language) achievement: Language learning orientation and autonomous learning. International Online Journal of Educational Sciences, 7(1), 160-171. http://dx.doi.org/10.15345/iojes.2015.01.014

Kozan, M.K., Ergin, C. \& Varoglu, D. (2007). Third party intervention strategies of managers in subordinates' conflicts in Turkey. International Journal of Conflict Management, 18(2), 128-147. https://doi. org/10.1108/10444060710759345

Little, D. (2007) Language Learner Autonomy: Some Fundamental Considerations Revisited. International Journal of Innovation in Language Learning and Teaching, 1(1), 14-29. https://doi.org/10.2167/illt040.0

Maehr, M. L. (1976). Continuing motivation: An analysis of a seldom considered educational outcome. Review of Educational Research, 46(3), 443-462. https://doi.org/10.3102/00346543046003443

Maehr, M. L. (1984). Meaning and motivation: Toward a theory of personal investment. Research on Motivation in Education, 1, 115-144.

McMahon, M. J. (2016) The adoption of a virtual learning environment among "digital Immigrant" engineering lecturers: A case study. Irish Journal of Academic Practice, 5(1), Article 3. https://doi.org/10.21427/D78B04

Merchant, K. (2012). How men and women differ: Gender differences in communication styles, influence tactics, and leadership styles. CMC Senior Theses.

Nakata, Y. (2011). Teachers' readiness for promoting learner autonomy: A study of Japanese EFL high school teachers. Teaching and Teacher Education, 27(5), 900-910. https://doi.org/10.1016/j.tate.2011.03.001

Oishi, D., Diener, E., Suh, E. M., \& Lucas, R. E. (1999). Value as a moderator in subjective well-being. Journal of Personality and Social Psychology, 69, 915-924. https://doi.org/10.1111/1467-6494.00051

Opdenakker, M. C., \& Damme, J. V. (2007). Do school context, student composition, and school leadership affect school practice and outcomes in secondary education? British Educational Research Journal, 33(2), 179-206. https://doi.org/10.1080/01411920701208233

Özkal, N., \& Demirkol, A. Y. (2014). Opinions of teachers on the necessity and execution of learners' Autonomy support. Education Sciences, 9(3), 293-310. https://doi.org/10.12739/NWSA.2014.9.3.1C0619

Peacock, M. (2001). Match or mismatch? Learning styles and teaching styles in EFL. International Journal of Applied Linguistics, 11(1), 1-20. https://doi.org/10.1111/1473-4192.00001

Reeve, J., Bolt, E., \& Cai, Y. (1999). Autonomy-supportive teachers: How they teach and motivate students. Journal of Educational Psychology, 91, 537-548. https://doi.org/10.1037/0022-0663.91.3.537

Reeve, J. (2002). Self-determination theory applied to educational setting. In E. L. Deci, \& R. M. Ryan (Eds.), Handbook of self-determination research (pp. 183-203). University of Rochester Press.

Reeve, J., Jang, H., Carrell, D., Jeon, S., \& Barch, J. (2004). Enhancing students' engagement by increasing teachers' autonomy support. Motivation and Emotion, 28(2), 147-169. https://psycnet.apa.org/doi/10.1023/ B:MOEM.0000032312.95499.6f

Reeve, J., \& Jang, H. (2006). What teachers say and do to support students' autonomy during a learning activity. Journal of Educational Psychology, 98(1), 209-214. https://doi.org/10.1037/0022-0663.98.1.209

Richards, J. C., \& Lockhart, C. (1994). Reflective teaching in second language classrooms. Cambridge University Press.

Strober, M. H., \& Tyack, D. (1980). Why do women teach and men manage? A report on research on schools. Signs: Journal of women in culture and society, 5(3), 494-503. https://doi.org/10.1086/493734

Şakrak-Ekin, G., \& Balçıkanlı, C. (2019). Does Autonomy Really Matter in Language Learning? Journal of Language and Education, 5(4), 98-111. https://doi.org/10.17323/jle.2019.8762

Wang, M. T., \& Eccles, J. S. (2016). Retracted: Multilevel Predictors of Math Classroom Climate: A Comparison Study of Student and Teacher Perceptions. Journalof Research on Adolescence, 26(3), 617-634. https://doi. org/10.1111/jora. 12153

$\mathrm{Wu}, \mathrm{X}$. (2003). Intrinsic motivation and young language learners: The impact of the classroom environment. System, 31, 501 - 517. https://doi.org/10.1016/j.system.2003.04.001

Yeşilyurt, S. (2008). A Self-Determination approach to teaching writing [Unpublished doctoral dissertation]. Atatürk University.

Zimmerman, B. J. (2000). Self-efficacy: An essential motive to learn. Contemporary Educational Psychology, 25(1), 82-91. https://doi.org/10.1006/ceps.1999.1016 


\section{Appendix A}

\section{AUTONOMY ORIENTATIONS QUESTIONNAIRE}

Dear Colleague,

In this questionnaire, there are ten situations that language instructors who work in a preparatory language school can come across, and each of these ten situations has four different options of responding to it. Please rate the degree of appropriateness of each of the four options (on a 7-point scale) for each of the ten situations. If you consider the option to be extremely appropriate respond to the option with the number " 7 " or if you consider the response highly inappropriate respond with the number " 1 ". Thus, there are 40 ratings. There are no right or wrong ratings on these items. People's styles differ, and we are simply interested in what you consider appropriate given your own style. Please respond to each of the 40 items using the following scale:

very inappropriate 2-3- 4 moderately appropriate 5-6-7 very appropriate

A. Cem is an average student who is at B level. During the past two weeks he has not been participating in the class activities. The work he does in the class is accurate but he has not been completing tasks. The most appropriate thing for Cem's teacher to do is to:

1. Impress upon him the importance of finishing his tasks since he needs to learn this material for his own good. (MC)

2. Let him know that he doesn't have to finish all of his work now and see if it is possible to help him work out the cause of the listlessness. (HA)

3. Make him stay for more practice after the class. (HC)

4. Let him see how he compares with the other students in terms of his assignments and encourage him to catch up with the others. (MA)

B. At a teachers' meeting it was mentioned that Selen has made more progress than expected since the last meeting. All teachers hope she continues to improve so that she does not have to repeat the preparatory year. They have been expecting this since her last midterm exam results. The teachers decide that the best thing to do is to:

5. Promise her a cinema ticket to her favorite film if she continues to improve. (HC)

6. Tell her that she's now doing as well as many of the other students in her class. (MA)

7. Tell her about the report, letting her know that they're aware of her increased independence in school. (HA)

8. Continue to emphasize that she has to work hard to get better grades. (MC)

C. Deniz loses his temper a lot and has a way of agitating other students. He doesn't respond well to what the teacher tells him to do and the teacher is concerned that he will disturb his class. The best thing for the teacher to do with him is to:

9. Emphasize how important it is for him to "control himself" in order to succeed in his academic and social life. (MC)

10. Ask the director to change his classroom. (HC)

11. Help him see how other students behave in these various situations and praise him for doing the same. (MA)

12. Realize that Deniz is probably not getting the attention he needs and start being more responsive to him. (HA)

D. One of Ms. Cansever's students is a very good player on the university football team, which has been winning most of its games. However, she is concerned because he has been missing most of his quizzes due to the games and has not been doing his homework. The best thing to do is to: 
13. Ask him to talk about how he plans to handle the situation. (HA)

14. Tell him he ought to decide to give up football so he can catch up in his classes. (MC)

15. See if others on the team are in the same dilemma and suggest he does as much preparation as the others. (MA)

16. Make him miss tomorrow's game to study; football has been interfering too much with his school work. (HC)

E. The Beginner-1 level group has been having trouble catching up with the other groups all year. The best thing for Miss Vatan to do is to:

17. Organize competitions in English so that they will be motivated to do better. (MA)

18. Make them practice more and give them special rewards for improvements. (HC)

19. Have each student keep a notebook and emphasize how important it is. (MC)

20. Help the group devise ways of learning together (games, and so on). (HA)

F. In Mr. Coşkun's class there is a female student named Mehtap. She is quiet and usually alone. Despite the efforts of all her teachers, Mehtap has not been accepted by the other students. The best thing for Mr. Coşkun to do is to:

21. Push her into interactions and provide her with a lot of praise for any social initiative. (HC)

22. Talk to her and emphasize that she should make friends, so she'll be happier. (MC)

23. Invite her to talk about her relationships with the other students and encourage her to take small steps when she is ready. (HA)

24. Encourage her to observe how other students relate and to join in with them. (MA)

G. For the past few weeks, things have been disappearing from the teacher's desk and a student's money has been stolen. Today, Mehmet was seen by the teacher taking a pen from her desk. The best thing for the teacher to do is to:

25. Talk to him about the consequences of stealing and what it would mean in relation to the other students. (MA)

26. Talk to him about it, expressing your confidence in him and attempting to understand why he did it. (HA)

27. Report this situation to the school's manager; stealing is something that cannot be tolerated, and he has to learn that. (HC)

28. Emphasize that it was wrong and have him apologize and promise not to do it again. (MC)

H. Mr. Arthur's student Canan has been getting average grades, and he'd like to see her improve. The best thing to do is to:

29. Encourage her to talk about her grades and what they mean to her. (HA)

30. Go over her grades with her; point out where she stands in the class. (MA)

31. Stress that she should do better; she'll not be able to finish preparatory school with grades like these. (MC)

32. Offer her big rewards for every A and smaller ones for every B for her future grades. (HC)

I. There is a student in Miss Tarçın's class who insists on using his mobile phone during the lesson even though she has warned him many times not to do so. The best thing to do is to:

33. Talk to him about why they have such a rule in class and the consequences he will face if he keeps using his mobile phone during the lessons, including getting a lower grade. (MC)

34. Warn him one more time telling him this is his last chance before he gets a time out. (HC)

35. Talk to him and assure him that his attention is very necessary in class. (MA)

36. Convince him it is distracting her and hindering her teaching performance in class. Not for him but for the teacher he needs to stop, so that she can teach to her full potential. (HA) 
J. One of Mrs. Ander's students has a serious attendance problem and she knows that it is going to result in his failure that year. The best thing for Mrs. Ander to do is to:

37. Make him talk to a previous student who has failed due to the same reason (absenteeism) and make him see how regretful this previous student is. (HA)

38. Get his friends involved and try to convince him to come to class regularly. (MA)

39. Have a private talk with him in order to find out why he really doesn't come to class and try to help with whatever problem he is having. (MC)

40. He needs to take responsibility for his own behavior and face any kind of results that he causes. He is not a child anymore. (HC) 


\section{Appendix B}

\section{EVALUATION QUESTIONS}

1. According to the "Motivators' Orientations Questionnaire" that was applied for the purposes of this study, the mean of the Autonomy Scores of the EFL teachers working at AUSFL was $\mathbf{4 0 . 3}$ which correlates to a Moderately Autonomy Supportive orientation. You can find a representation of the scores one could possibly get from this questionnaire below. How would you evaluate this situation? What do you think the possible reasons behind this result are?

\begin{tabular}{|l|l|l|l|l|l|}
\hline \multicolumn{2}{|c|}{ Min. -180} & -90 & \multicolumn{4}{|l|}{+90} & +180 Max. \\
\hline & $\begin{array}{l}\text { Highly } \\
\text { Controlling }\end{array}$ & $\begin{array}{l}\text { Moderately } \\
\text { Controlling }\end{array}$ & $\begin{array}{l}\text { Moderately } \\
\text { Autonomy } \\
\text { Supportive }\end{array}$ & $\begin{array}{l}\text { Highly } \\
\text { Autonomy } \\
\text { Supportive }\end{array}$ \\
\hline
\end{tabular}

2. When we take a look at the results in terms of gender differences, it was found that female teachers were slightly more autonomy supportive compared to their male colleagues. How would you evaluate this situation? What do you think the possible reasons behind this result are?

3. In the study, it was also investigated whether the Autonomy scores varied according to the teachers' years of experience or their department of graduation (ELT / non-ELT).It was found that neither of these variables made a significant difference. How would you evaluate this situation? What do you think the possible reasons behind this result are?

4. Your personal Autonomy Orientation score out of this questionnaire was " $X$ ". According to the figure presented on the previous page, how would you evaluate this situation? What do you think the possible reasons behind this result are?

5. Do you think EFL teachers should be more Autonomy Supportive? Why?

6. In order for the EFL teachers to become more Autonomy Supportive, what do you think should be done personally and institutionally? Why? 